\title{
A PUBLIC HEALTH APPROACH TO REGULATING FIREARMS AS CONSUMER PRODUCTS
}

\author{
JON S. VERNICK, J.D., M.P.H. ${ }^{\dagger}$ AND STEPHEN P. TERET, J.D., M.P.H. ${ }^{+}$
}

\section{INTRODUCTION}

It is indisputable that firearms are consumer products. In the United States, there are an estimated 192 million firearms in private hands. ${ }^{1}$ Broadly speaking, firearms can be divided into two categories: handguns and long guns. About sixty-five million of all civilian-owned firearms are handguns. ${ }^{2}$ More than one in three households have at least one firearm, and about one in four U.S. adults personally own one. $^{3}$ In rural areas and certain regions of the country, ownership rates are still higher. Like other consumer products, firearms are manufactured by foreign and domestic corporations, then sold to consumers through a system of distributors and dealers. In 1998, about 1.2 million handguns were produced in the United States; 532,000 more were imported. ${ }^{4}$ Also like most consumer products, firearms are advertised in both specialized publications and mainstream media. ${ }^{5}$

$\uparrow$ Assistant Professor of Health Policy and Management, Johns Hopkins School of Public Health; Associate Director, Johns Hopkins Center for Gun Policy and Research; Co-Director, J.D./M.P.H. Joint Degree Program at Johns Hopkins School of Public Health and Georgetown University Law Center; B.A., Johns Hopkins University; J.D., George Washington University; M.P.H., Johns Hopkins School of Public Health.

† Professor of Health Policy and Management, Johns Hopkins School of Public Health; Director, Johns Hopkins Center for Gun Policy and Research; Adjunct Professor of Law, Georgetown University Law Center; Co-Director, J.D./M.P.H. Joint Degree Program at Johns Hopkins School of Public Health and Georgetown University Law Center; B.A., St. Lawrence University; J.D., Brooklyn Law School; M.P.H., Johns Hopkins School of Public Health.

The authors wish to acknowledge the assistance of Emile LeBrun, M.A., and the support of the Joyce Foundation of Chicago, Illinois, in the preparation of this Article.

${ }^{1}$ See PHIIIP J. COOR \& Jens LudWig, U.S. DEP'T OF Justice, Guns IN AMERICA: NATIONAI SURVEY ON PRIVATE OWNERSHIP AND USE OF FIREARMS 13 (1997).

${ }^{2}$ See id.

See id. at 13, 14.

- See Bureau of Alcohol, Tobacco \& Firearms, ANNUAl Firearms MANUFACTURING AND EXPORT REPORT (1999).

${ }^{5}$ See Jon S. Vernick et al., Regulaling Firearm Advertisements that Promise Home Prolection: A Public Health Intervention, 277 JAMA 1391, 1392 (1997) (noting that firearm ad- 
There are also important differences between firearms and other consumer products. Unlike nearly all other products commonly found in households, firearms are specifically designed to injure or kill. As a result, there were more than 32,000 firearm-related deaths in the United States in $1997,{ }^{6}$ and approximately another 64,000 serious nonfatal injuries. ${ }^{7}$ In addition, more than 670,000 violent crimes were committed with firearms in $1998 .^{8}$

This special deadliness increases the need to regulate firearms. In the United States, however, we have failed to regulate firearms in the manner we regulate even less deadly consumer products. In particular, we have not implemented comprehensive product-based regulation of firearms, as we have effectively done for other consumer products, in order to reduce the incidence of firearm-related injuries.

As public health researchers and teachers, our reasons for arguing that consumer-product regulation of firearms is needed are neither philosophical nor ideological. Rather, they are based on our understanding of the potential benefits of gun regulation for the public's health.

This Article will (1) briefly summarize how firearms are currently regulated and highlight the gaps in that regulation; (2) discuss the elements of a comprehensive system to regulate firearms as consumer products; (3) present several regulatory alternatives for implementing and maintaining such a system; (4) explain what is known about the likely benefits of such a system; and (5) anticipate and respond to several arguments that may be raised to oppose consumer-product regulation.

vertisements appear not only in magazines devoted to guns, but also in "general magazines" with wider distribution).

'See Donna L. Hoyert et al., Deaths: Final Data for 1997, 47 NAT'L VITAL STAT. REP. 68 tbl.16 (1999) (reporting the number of firearm deaths in the United States by age, race, and sex).

${ }^{7}$ See Center for Disease Control and Prevention, U.S. Dep't of Health \& Human Servs., Nonfatal and Fatal Firearm-Related Injuries-United States, 1993-1997, 48 MORBIDITY \& MORTALITY WKLY. REP. 1029, 1031 (1999) (reporting national estimates of nonfatal firearm-related injuries in the United States from 1993-1997).

${ }^{3}$ See CaIIIE M. RENNISON, U.S. DEP'T Of JUSTICE, CRIMINAI Victimization 1998, at 7 (1999) (providing victim-reported data of the use of weapons in violent crimes in 1998). 


\section{HOW FIREARMS ARE CURRENTLY REgULATED: AN OVERVIEW}

In the United States, there are laws governing firearms at the federal, state, and local levels. One way to think about the structure of these laws is to imagine the history of a given gun as including its (1) design, manufacture, and marketing; (2) sale; (3) possession; and (4) use. ${ }^{9}$ Although some argue that there are already numerous laws governing firearms, the majority of these are criminal laws proscribing certain uses of firearms, such as harming someone or committing a crime. Most of these are promulgated at the state or local level.

A number of laws also govern the possession of firearms. Under both federal and state laws, convicted felons, ${ }^{10}$ among other categories of persons, ${ }^{\text {II }}$ may not possess firearms. Juveniles may not possess handguns, ${ }^{12}$ but they may possess long guns. Firearm possession is also proscribed in certain places, such as school zones ${ }^{13}$ and courthouses, subject to limited exceptions. State laws also establish rules defining who may carry a concealed firearm. ${ }^{14}$

Regarding the sale of guns, under the federal Gun Control Act of 1968, a person engaged in the business of selling firearms must obtain a dealer's license. ${ }^{15}$ Some states also require gun dealers to obtain a license. Licensed dealers may not sell handguns to persons younger

${ }^{9}$ See Stephen P. Teret \& Garen J. Wintemute, Policies To Prevent Firearm Injuries, 12 HEALTH AFF. 96, 98-101 exhibit 1 (1993) (categorizing the major options for legislative and regulatory policy at the federal, state, and local levels).

${ }^{10}$ See 18 U.S.C. $§ 922$ (g) (1) (1994) (prohibiting gun ownership by any person convicted in any court of a crime punishable by more than one year).

"Other categories of persons proscribed from firearms possession include: fugitives from justice, drug addicts, those who have been committed to mental institutions, illegal aliens, renunciates of U.S. citizenship, those dishonorably discharged from the Armed Forces, and persons convicted of certain domestic violence-related misdemeanors or subject to domestic violence restraining orders. See 18 U.S.C. $§ 922(\mathrm{~g})$ (1994) (listing categories of persons precluded from gun ownership).

${ }^{12}$ See 18 U.S.C. $\$ 922(x)(2)$ (1994) (forbidding juveniles from owning handguns or handgun ammunition, subject to certain exceptions).

${ }^{13}$ See 18 U.S.C. $\$ 922(q)(2)(A)$ (1994) (banning firearm possession in school zones).

1 See, e.g., Jens Ludwig, Concealed-Gun-Carrying Laws and Violent Crime: Evidence From State Panel Data, 18 INT'L REV. L. \& ECON. 239, 240 (1998) (discussing state "shall-issue" laws requiring concealed-carry permits to be issued to applicants who meet certain criteria); Daniel W. Webster et al., Flawed Gun Policy Research Could Endanger Public Safely, 87 AM. J. PUB. HEALTH 918 (1997) (discussing state "shall-issue" and "may-issue" laws).

${ }^{15}$ See 18 U.S.C. \$ 923 (1994) (regulating the licensing of firearms dealers, manufacturers, importers, and collectors). 
than age twenty-one, or long guns to those younger than eighteen. ${ }^{16}$ In addition, licensed dealers must collect information from prospective purchasers so that state or federal authorities can perform a criminal history background check. ${ }^{17}$ In some states, the background check includes a waiting period; in others, the check is performed immediately over the telephone.

Noticeably absent in the United States, however, are laws governing the design, manufacture, and marketing of firearms. The Consumer Product Safety Commission ("CPSC") has federal regulatory authority over most consumer products, ${ }^{18}$ although other federal agencies oversee the design of some products, like motor vehicles, boats, and medical devices. Virtually alone among consumer products, ${ }^{19}$ for firearms, no federal agency has the authority to establish standards for their safe design. In fact, Congress has expressly forbidden the CPSC from exerting regulatory authority over firearms and ammunition. $^{20}$ Although the Bureau of Alcohol, Tobacco, and Firearms ("ATF") has the authority to implement specific gun laws, such as portions of the Gun Control Act, it has no broad regulatory authority over firearms.

In the absence of a comprehensive federal regulatory scheme for gun design, only a few individual federal and state laws address this issue. Under the Gun Control Act, no handgun may be imported unless it is "particularly suitable for or readily adaptable to sporting pur-

${ }^{16}$ See 18 U.S.C. $\$ 922$ (b) (1) (1994) (forbidding the sale of all firearms by licensed dealers to those under eighteen years of age and all firearms, except shotguns and rifles, to those under twenty-one).

${ }^{17}$ See 18 U.S.C. $\$ 922$ (s) (1994) (enumerating the information on purchasers that must be collected and the procedures by which it must be collected); 18 U.S.C. $\S$ 922( $\mathrm{t}$ ) (1994) (mandating that dealers in most states must contact the national instant criminal background check system instituted in 1998 under the so-called "permanent" provisions of the Brady Act).

${ }^{18}$ See 15 U.S.C. $\$ 2052$ (1994) (defining "consumer products" for the purpose of CPSC's jurisdiction).

${ }^{19}$ The design of tobacco products like cigarettes is also virtually unregulated. See, e.g., Food \& Drug Admin. et al. v. Brown \& Williamson Tobacco Corp., No. 98-1152, 2000 WL 289576, at *23 (U.S. Mar. 21, 2000) (holding that Congress did not grant the FDA regulatory authority over tobacco products). But see John M. Broder, Bush and Gore See Ruling as Prod for New Controls, N.Y. TIMEs, Mar. 22, 2000, at A23 (reporting that the two presidential candidates endorsed "stricter controls on tobacco products").

${ }^{20}$ See Consumer Product Safety Commission Improvements Act of 1976, Pub. L. No. 94-284, § 3(e), 90 Stat. 503, 504 (1976) ("The Consumer Product Safety Commission shall make no ruling or order that restricts the manufacture or sale of firearms, firearms ammunition, or components of firearms ammunition, including black powder or gunpowder for firearms."). Ironically, the CPSC could choose to regulate nonpowder firearms, like BB guns or air guns, as well as toy guns. 
poses. ${ }^{21}$ To implement the sporting-purposes test, ATF has established what are called "factoring criteria" to be applied to each imported handgun. The factoring criteria establish minimum-size standards and consider a handgun's safety features and other design factors to determine whether a handgun may be imported. ${ }^{22}$ No comparable federal laws apply to domestically manufactured handguns, although some states do ban domestically-made Saturday night specials. ${ }^{23}$ A recent federal law also banned so-called "assault weapons," originally civilian versions of military firearms. ${ }^{24}$ Nineteen such weapons are banned by name, and numerous others are also outlawed if they possess some combination of design features such as a detachable magazine, barrel shroud, or bayonet mount. Finally, federal law prohibits the possession and sale of new ammunition magazines that hold more than ten rounds of ammunition. ${ }^{25}$

\section{How to REgULATE FIREARMS AS CONSUMER PRODUCTS}

A comprehensive consumer product-based regulatory scheme for firearms would include the following: (1) standards for safe design; (2) closer regulation of firearm models that are particularly dangerous or attractive to criminals; (3) surveillance and recall authority; (4) improved manufacturer and government oversight of firearm dealers and distributors; (5) requirements for responsible advertising practices; and (6) no immunity from litigation for firearm manufacturers.

Design standards are at the heart of regulating firearms in the same manner as other consumer products. Unfortunately, left to themselves, firearm manufacturers have not uniformly incorporated feasible safety technologies into the design of handguns. In fact, the general trend in handgun design has been to increase lethality rather than safety. ${ }^{26}$ Recently, for example, there has been a shift among

${ }^{21} 18$ U.S.C. $\$ 925(d)(3)$ (1994).

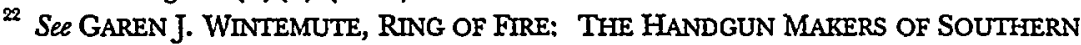
CAIIFORNIA 66-67 tbl.5-1 (Report from the Violence Prevention Research Program) (1994) (describing the factoring criteria applied by ATF to "handguns proposed for importation").

${ }^{23}$ These states are California, Hawaii, Illinois, Maryland, Massachusetts, Minnesota, and South Carolina.

${ }^{24}$ See 18 U.S.C. $\$ 922$ (v)(1) (1994) (outlawing semiautomatic assault weapons).

${ }^{25}$ See 18 U.S.C. $\$ 922(w)(1)$ (outlawing possession of a "large capacity ammunition feeding device").

${ }^{26}$ See Garen J. Wintemute, The Relationship Between Firearm Design and Firearm Violence: Handguns in the 1990s, 275 JAMA 1749, 1753 (1996) (asserting that the evolution in handgun design will affect rates of firearm violence and may lead to "an increase in 
manufacturers toward the production of semiautomatic pistols rather than revolvers. ${ }^{27}$ Most pistols can hold more ammunition in their magazine or clip than revolvers hold in their rotating cylinder, thereby increasing the opportunity for multiple wounds. ${ }^{28}$ In addition, there has been a trend toward higher caliber handguns. Other things being equal, higher caliber ammunition can produce more serious injuries than lower caliber ammunition. Other factors, such as the widespread availability of and media attention given to laser sighting devices, may also increase the overall lethality of handguns. ${ }^{29}$

This trend toward increased firearm lethality can be reversed. There are design changes to firearms that can actually reduce the risks they pose to both individuals and society. For example, a personalized gun is designed to be operable only by an authorized user. Sometimes also called "smart guns," these firearms have been patented, though generally not manufactured, for many years. Recently, however, SigArms has developed a new gun that uses personalization technology, which the company expects to market in the near future. The new gun has a built-in key pad requiring the authorized user to enter a personalized identification number. The gun can be set so that it will not operate unless the user enters the correct code, and includes a timer that can be programmed to relock the gun after a certain period of time has elapsed. Additional ways to personalize guns are also being developed, including guns that will identify the fingerprints of their authorized user(s). ${ }^{30}$

the case-fatality rate for all types of shootings").

${ }^{27}$ In 1985 , handgun manufacturers made more revolvers than pistols $(844,000$ revolvers compared with 707,000 pistols). By 1993 , about four times as many semiautomatic pistols $(2.2$ million) as revolvers $(550,000)$ were produced. See BUREAU OF

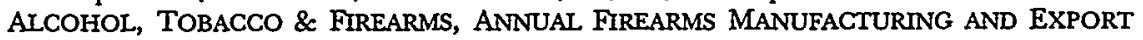
REPORT (1994).

${ }^{28}$ See Daniel W. Webster et al., Epidemiologic Changes in Gunshot Wounds in. Washington, DC, 1983-1990, 127 ARCHIVES OF SURGERY 694, 698 (1992) (reporting that the mean number of gunshot wounds increased significantly for patients at a Level I trauma center from 1983 to 1990, the same time period in which "more and more assailants ha[d] switched from revolvers to high-capacity semiautomatic pistols").

${ }^{29}$ See Wintemute, supra note 26, at 1752-53 (describing laser aiming devices and asserting that they cannot reduce the frequency of accidental shootings in the home, and that the media attention given to such devices may help "increase[] their involvement in violence").

so See KRISTA D. ROBINSON ET AL., JOHNS HOPKINS GTr. FOR GuN POLICY AND RESEARCH, PERSONALIZED GuNS: REDUCiNG Gun DEATHS Through DESIGN CHANGES 5-9 (2d ed. 1996) (describing personalization technologies, including both devices that can be fitted to the firearm after purchase and technologies that can be included as an original part of the gun); Stephen P. Teret et al., Making Guns Safer, IsSUES IN SCI. \& TECH., Summer 1998, at 37, 38-39 (describing fingerprint-reading and other personal- 
Personalized guns might prevent several different kinds of firearm-related deaths and injuries. Such technology can prevent firearm suicides or unintentional deaths in which the person pulling the trigger, for example a juvenile, is not the gun's owner or authorized user. In addition, if personalized guns are not readily operable by criminals who might steal them, even some homicides may be prevented.

Other design features intended to prevent certain unintentional shootings are included on some, but not all, handguns. A loadedchamber indicator is a device designed to indicate to a user or observer if the gun contains ammunition ready to be fired. Because semiautomatic pistols may retain one ammunition round in the firing chamber after the ammunition magazine has been removed, this device can prevent accidental shootings where the shooter mistakenly believes that the gun is not loaded. A magazine safety, sometimes called a magazine disconnect safety, is also designed to prevent some of these shootings by automatically preventing the pistol from firing when its ammunition magazine has been removed, even if one round remains in the firing chamber. Despite the lifesaving potential of these devices, they are available on only about ten percent of new pistol models.

In addition to mandating certain design changes, comprehensive regulation of firearms as consumer products would include several additional elements. As with other products, the most potentially dangerous designs can be more heavily regulated or banned completely. ${ }^{32}$ As previously mentioned, Congress has already banned assault weapons and imported Saturday night specials. Domestically manufactured Saturday night specials, sometimes called "junk guns," however, remain lawful in most states. Models of these handguns are among the guns most frequently traced to crime. ${ }^{33}$ A comprehensive regulatory scheme would examine these and other guns to assess

ization technologies).

s1 See Jon S. Vernick et al., I Didn't Know the Gun Was Loaded: An Examination of Two Safety Devices That Can Reduce the Risk of Unintentional Firearm Injuries, 20 J. PUB. HEALTH POL'Y 427, 433 (1999) (reporting that $11 \%$ of 1998 pistol models contained a loaded chamber indicator and $14 \%$ contained a magazine safety).

${ }^{32}$ For example, the CPSC has banned certain especially hazardous products, such as lawn darts and three-wheel all terrain vehicles ("ATV"s).

${ }^{33}$ See MARIANNE W. ZAWTIZ, U.S. DEP'T OF JUSTICE, GUNS USED IN CRIME 5 (1995) (listing the ten guns most frequently traced to crime in 1994, seven of which are made by "Ring of Fire" manufacturers, as noted by WINTEMUTE, supra note 22); Stephen W. Hargarten et al., Characteristics of Firearms Involved in Fatalities, 275 JAMA 42, 43 (1996) (discussing a population-based study that documents the proportion of deaths associated with specific types of firearms). 
whether additional regulation is necessary. Rather than banning these particularly dangerous weapons, one approach is to closely monitor their ownership and transfer. For example, fully-automatic weapons (or machine guns) have been very closely regulated since the 1930s. Such regulation has required registration of the gun and licensing of its owners. ${ }^{34}$ Consequently, machine guns are very rarely used in crime.

For most other consumer products, a mechanism is also in place to determine which models pose an increased risk of harm (what public health professionals call a "surveillance system") and to order a recall to repair or replace defective merchandise. For example, the CPSC maintains the National Electronic Injury Surveillance System ("NEISS") to track product-related deaths and injuries. The National Highway Traffic Safety Administration ("NHTSA") maintains the Fatality Analysis Reporting System ("FARS") to monitor deaths and injuries associated with motor vehicles. No such system exists for firearms. $^{35}$ As a result, it is difficult for researchers, policy-makers, and even the firearm manufacturers themselves to determine which firearms pose special dangers and to respond appropriately. The absence of such a system became especially noticeable when Sturm Ruger \& Company, Inc. ("Sturm Ruger") manufactured a replica of an oldWest revolver without including a modern safety feature to prevent accidental firing. Sturm Ruger began a voluntary recall of its gun only after numerous deaths, injuries, and corresponding lawsuits. Still, many of the firearms were never fixed and remain in circulation. ${ }^{36}$

One important component of an effective surveillance and recall system is for firearms to possess truly unique serial numbers that encode information about the make, model, year, and other characteristics of the weapon. Such a system is currently used for motor vehicles. $^{37}$ Although federal law does require firearms to contain serial

${ }^{s t}$ See 26 U.S.C. $\$ \S 5811,5812,5841,5861$ (1994).

35 See Stephen P. Teret et al., The Firearm Falality Reporting System: A Proposal, 267 JAMA 3073, 3073 (1992) (advocating the development of a "national fatal firearm injury reporting system" comparable to FARS).

${ }^{96}$ The feature, a transfer-bar safety, prevents the revolver's hammer from contacting the firing pin unless the trigger is pulled. Without such a system, the Sturm Ruger revolvers could be fired if simply dropped or bumped. The device was added as part of Sturm Ruger's belated recall effort. See TRUDY ANN KARLSON \& STEPHEN W. HARGARTEN, REDUCING FIREARM INJURY AND DEATH: A PUBLIC HEAITH SOURCEBOOK ON GuNS $41-42$ (1997) (commenting that Sturm Ruger continued to sell its remaining stock of firearms without the transfer-bar safety from 1973 until the 1980s).

${ }^{97}$ These are called Vehicle Identification Numbers, or VINs, and their content is prescribed by 49 C.F.R. $\S \S 565.1-565.7$ (1999). 
numbers, ${ }^{38}$ no standard system is used to encode this information, and the numbers are easily obliterated. In addition to allowing manufacturers to track their products more easily and issue recalls as needed, a more efficient serial number system could also be used by the police to facilitate prosecutions and deter illegal gun sales.

Standards for the marketing and advertising of firearms would also contribute to a consumer-product approach. Currently firearm manufacturers do not effectively monitor the practices of their dealers and distributors. Firearms can enter the criminal market when dealers either knowingly or negligently make sales to unauthorized persons. ${ }^{39}$ One all-too-common form of illegal sale is called a "straw purchase," where someone without a criminal record buys the gun for the real buyer, a proscribed purchaser. Regulations can compel firearm manufacturers to train dealers to identify signs of a straw purchase and to refuse to supply guns at all to dealers who fail to institute such practices. For another potentially dangerous product, alcoholic beverages, programs have been instituted to train servers not to supply alcohol to high-risk persons such as minors or intoxicated persons.

Advertisements for firearms should be regulated in the same manner as advertisements for other products. The best available research suggests that homes with guns are more likely to experience a homicide or suicide than homes without guns. ${ }^{41}$ Yet advertisements for handguns have touted the home or personal protection benefits of the product, without mentioning the potential risks. ${ }^{42}$ Other advertisements have depicted potentially unsafe storage practices such as a handgun left unlocked on a nightstand table, with loose ammunition

${ }^{2 s}$ See 27 C.F.R. $\$ 178.92$ (a) (1) (1999) (requiring that a serial number be placed on every firearm manufactured or imported).

${ }^{39}$ See Phillip J. Cook \& Thomas B. Cole, Strategic Thinking About Gun Markets and Violence, 275 JAMA 1765, 1765-66 (1996) (commenting that some firearms reach the streets because of "scofflaw dealers" who sell to prohibited purchasers).

${ }^{40}$ See U.S. DEP'T OF HEALTH \& HUMAN SERVS., supra note 40, at 313-14.

1 See David A. Brent et al., The Presence and Accessibility of Firearms in the Homes of Adolescent Suicides: A Case-Control Study, 266 JAMA 2989, 2989 (1991) (finding that the availability of guns in the home increases the risk of suicide among adolescents); Arthur L. Kellermann et al., Gun Ownership As a Risk Faclor for Homicide in the Home, 329 NEW ENG. J. MED. 1084, 1084 (1993) (concluding that "guns kept in the home are associated with an increase in the risk of homicide by a family member or intimate acquaintance"); Arthur L. Kellermann et al., Suicide in the Home in Relation to Gun Ownership, 327 NEW ENG. J. MED. 467, 471-72 (1992) (concluding that "the ready availability of firearms appears to be associated with an increased risk of suicide in the home").

${ }^{42}$ See Vernick et al., supra note 5, at 1394-95 (discussing firearm advertisements promising home protection and the legal remedies available to the Federal Trade Commission). 
nearby, in a home that apparently includes young children. In addition, one manufacturer has advertised its product in a way arguably designed to appeal to criminals. ${ }^{43}$ Although the Federal Trade Commission has regulatory authority over deceptive or unfair advertising, ${ }^{44}$ including advertisements for firearms, it has not yet responded to a petition filed in 1996 to disallow such advertisements.

In the absence of comprehensive consumer product regulation of firearms, both individuals and municipalities have recently filed lawsuits against firearm manufacturers and dealers. The lawsuits seek to recover the costs associated with firearm violence. The primary legal theories are that manufacturers failed to (1) incorporate feasible safety devices into the design of their products, including loaded chamber indicators, magazine safeties, and personalization technology; and (2) employ reasonable methods of marketing and of overseeing their distributors and dealers to reduce the likelihood that their products would be sold to criminals or youth. ${ }^{45}$ A parallel trend, however, has been for state legislatures to enact laws forbidding municipalities from suing the firearm industry, except under very limited circumstances. Some of these enacted or proposed laws would also apply to individual lawsuits. The National Rifle Association ("NRA") has led the lobbying effort for these laws. ${ }^{46}$ These immunity laws once again afford a different status to firearms than to other consumer products. Under the Consumer Product Safety Act, for example, even compliance with a federal safety standard does not preempt tort litigation against product manufacturers within the CPSC's purview. ${ }^{47}$ For a product whose safe design is virtually unregulated, such immunity would be particularly unfortunate for the public's health.

${ }^{43}$ That manufacturer, Navegar ( $d / b / a$ Intratec), has advertised its TEC-9 gun as featuring "resistance to fingerprints."

${ }^{44}$ See Federal Trade Commission Act, 15 U.S.C. $\$ 45$ (1999) (declaring unfair methods of competition unlawful).

${ }^{45}$ See Jon S. Vernick \& Stephen P. Teret, New Courtroom Strategies Regarding Firearms: Ton Litigation Against Firearm Manufaclurers and Constitutional Challenges to Gun Laws, 36 HOUS. L. REV. 1713, 1736-53 (1999).

${ }^{16} \mathrm{See} i d$. at 1753 .

47 See 15 U.S.C. $\$ 2074$ (a) (1999) (stating that common law liability is not precluded by compliance). 


\section{HOW TO IMPLEMENT CONSUMER PRODUCT REGULATIONS}

Consumer-product regulation of firearms might be implemented in several different ways. Congress could choose to lift the restrictions it imposed on the CPSC and allow that agency to exercise regulatory authority over firearms. This might have the advantage of relying on CPSC's existing expertise and infrastructure in the regulation of other consumer products. In fact, the CPSC's NEISS system has recently been used to provide estimates of nonfatal firearm injuries, though without attributing them to specific firearm models. ${ }^{48}$ In addition, the CPSC's status as a so-called "independent agency"-not directly answerable to either the executive or legislative branches-might facilitate an independence from the firearm industry to be regulated.

The CPSG, however, does not have substantial institutional expertise regarding firearms. Some have therefore suggested that ATF would be the more appropriate agency to be given consumer product authority over firearms. ATF has recently established tracing systems for all crime guns in selected cities. ${ }^{49}$ Data from this system can be used to better understand the relative risks of various gun models. ATF also has a history of working with firearm manufacturers and dealers to implement existing law. This could be an advantage, but also a disadvantage if ATF were unable to maintain an appropriate level of objectivity. In addition, ATF has limited, if any, experience in establishing design rules and monitoring recalls. ${ }^{50}$ Another regulatory option might be to create an entirely new agency, perhaps within the Department of Justice (ATF is part of the Department of the Treasury). The National Institute of Justice ("NIJ") is the research arm of the Department of Justice and has funded both research and the development of new firearm designs, including personalized guns. NIJ might serve as a valuable resource to a new agency.

However such regulations are implemented, public opinion supporting them is strong. In a random-digit-dial telephone survey, $68 \%$ of U.S. adults supported governmental regulation of gun design. ${ }^{51}$

4s See Joseph L. Annest et al., National Estimates of Nonfalal Firearm-Related Injuries: Beyond the Tip of the Iceberg, 273 JAMA 1749, 1749-54 (1995) (using the NEISS system to estimate nonfatal, firearm-related injuries from June 1992 to May 1993).

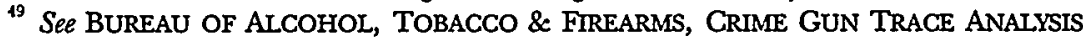
REPORTS: THE ILIEGAL FIREARMS MARKET IN 27 COMMUNITIES 1-2 (1998).

${ }^{30} \mathrm{Bul}$ see discussion supra note 22 and accompanying text (discussing the "factoring criteria" that ATF applies to imported handguns).

${ }^{31}$ See Stephen P. Teret et al., Support for New Policies to Regulnte Firearms, 339 NEW ENG. J. MED. 813, 814-15 (1998). 
Ninety-four percent favored applying the same standards for domestically-made guns as are already imposed on imported guns. ${ }^{52}$ More specific laws requiring personalized guns $(71 \%)$, loaded-chamber indicators $(73 \%)$, and magazine safeties $(82 \%)$ were all supported by a majority of respondents. ${ }^{53}$ In fact, even a majority of gun owners supported each of these devices. ${ }^{54}$

\section{THE PUBLIC HEALTH EFFECTS OF CONSUMER PRODUCT REgULATION}

Consumer-product regulation of firearms, like that outlined above, can save lives. Although the effectiveness of personalized guns, loaded chamber indicators, and magazine safeties has not been fully quantified-in part because firearm manufacturers have not yet widely implemented the technology-they can be expected to prevent some firearm-related deaths and injuries. In 1997, more than 1200 people aged ten to nineteen committed suicide with a gun. ${ }^{55}$ Another 142 children aged fourteen and younger were unintentionally killed by firearms. ${ }^{56}$ Personalized guns might prevent at least some of these deaths caused by unauthorized users, such as juveniles. A personalized gun would also not be operable by the criminal who disarms a police officer. From 1987 to 1996, more than seventy police officers were shot and killed with their own weapons. ${ }^{57}$

There are no reliable estimates of the number of shootings caused by persons mistakenly believing a gun is unloaded. In one survey, however, more than one-third of respondents did not know that a pistol can still be fired even if its ammunition magazine has been removed. $^{58}$ A study performed by the U.S. General Accounting Office

${ }^{52}$ See id.

${ }^{33}$ See id.

${ }^{54}$ See id.

${ }^{55}$ See National Center for Injury Prevention and Control, Center for Disease Control and Prevention, Firearm Suicide Deaths and Rates Per 100,000 (visited Nov. 19, 1999) <http://www.cdc.gov/ncipc/ncipchm.htm> (reporting firearm deaths by age, year, and intent).

${ }^{56}$ See Hoyert et al., supra note 6, tbl.16 (reporting the number of firearm deaths in 1997 in the United States, broken down by race, sex, age, and intent).

${ }^{57}$ See FEDERAL BUREAU OF INVESTIGATION, UNIFORM CRIME REPORTS: LAW ENFORCEMENT OFFICERS KILIED AND ASSAULTED 1996 (1998) (summarizing the assaults on law enforcement officers from 1987 to 1996).

${ }^{53}$ See Vernick et al., supra note 31 , at 430 (noting that $34.8 \%$ of respondents either did not know if a gun could be fired with its magazine missing or responded that it could not be fired). 
("GAO") examined the potential benefits of loaded chamber indicators. ${ }^{59}$ After examining a series of 107 accidental shootings that occurred in 1988-1989, the GAO concluded that twenty-three percent might have been prevented by a loaded-chamber indicator. ${ }^{60}$ Extrapolating to the number of accidental deaths in the United States at that time, the study concluded that 345 lives might have been saved by loaded chamber indicators.

The absence of effective firearm-injury surveillance systems makes it difficult to determine more precisely the likely effects of various safer gun designs. However, public health professionals can draw on the lessons learned from the implementation of safety standards for other products. For example, motor vehicles have been subject to numerous federal safety standards since the late $1960 \mathrm{~s}^{61}$ Since then, motor vehicle-related fatalities have declined dramatically. ${ }^{62}$ Certainly other factors have also contributed to the decline in motor vehicle deaths, but safe design standards have played an important role. ${ }^{63}$ Standards requiring childproof designs for cigarette lighters ${ }^{64}$ and aspirin bottles ${ }^{65}$ have also been associated with declines in accidental deaths.

Several studies suggest that banning particularly dangerous fire-

59 See GENERAL ACCOUNTING OFFICE, ACCIDENTAL SHOOTINGS: MANY DEATHS AND INJURIES CAUSED BY FIREARMS COULD BE PREVENIED (1991) (considering whether accidental shootings could be prevented by alterations to handguns).

${ }^{60}$ See id. at 17.

61 See 49 C.F.R. $\$ 571$ (1999) (setting out federal motor vehicle safety standards).

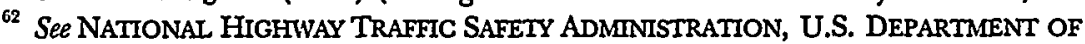
TRANSPORTATION, TRAFFIC SAFETY FACTS 1997, at 15 (1998).

${ }^{63}$ See Leon S. Robertson, Automobile Safely Regulations and Death Reductions in the United States, 71 AMER. J. PUB. HEALTH 818, 821 (1981) (concluding that a significant reduction in the loss of human life resulted from the imposition of federal motor vehicle safety standards beginning in 1968).

${ }^{64}$ See U.S. Consumer Product Safety Commission, CPSC and Industry: Saving Lives Cost-Effectively Through Cooperation (Child-Resistant Cigarette Lighters) (last modified May 5, 1996) <http://www.cpsc.gov/cpscpub/pubs/success/lighters.html>.

${ }^{65}$ David Kopel has elsewhere cited a study claiming that safety caps on medicine bottles actually increased accidental deaths by causing people to be "more careless about storing medicine out of the reach of children." Dave Kopel \& Eugene Volokh, Loaded Guns Can Be Good for Kids (visited Mar. 18, 2000) <http://www.i2i.org/ SuptDocs/OpEdArcv/1999/LoadedGuns.htm> (asserting that poisoning deaths increased as a result of the federal mandate on safety caps, and drawing an analogy to mandatory gun locks). Subsequent research has rebutted this contention. See Gregory B. Rodgers, The Safety Effects of Cliild-Resistant Packaging for Oral Prescription Drugs: Two Decades of Experience, 275 JAMA 1661, 1661, 1664 (1996) (estimating that safety cap regulations resulted in a reduction of about 460 child deaths between 1974 and 1992 and concluding that safety caps on medicine bottles reduce child mortality from unintentional ingestion of oral prescription drugs). 
arm designs will reduce the likelihood that guns incorporating those designs will be used in crime. Maryland is one of seven states that has banned Saturday night specials, and in Baltimore, these banned guns make up a much smaller proportion of the guns used in crime than in other cities that do not ban them. ${ }^{66}$ Similarly, since federal law banned certain semiautomatic assault weapons, these guns, though never a significant share of the crime problem, are even less frequently involved in crime. ${ }^{67}$ Some jurisdictions, such as Washington, D.C. and Chicago, have chosen to ban all handguns. An evaluation of Washington's law concluded that it was associated with an approximately twenty-five percent decline in firearm-related homicides and suicides between 1976 and $1987 .^{68}$

Tort litigation can be an important complement to effective regulation. By providing manufacturers with economic incentives to make their products safer, litigation can serve a public-health purpose. ${ }^{69}$ When manufacturers or regulators fail to keep up with innovations in design, litigation allows individual citizens or municipalities to force manufacturers to design or market their products more safely. Although a cause and effect relationship is difficult to prove, shortly after the first verdict against firearm manufacturers finding liability for negligently marketing their products, ${ }^{70}$ one major manufacturer required its dealers to adhere to a new code of conduct. ${ }^{n}$ Examples in

${ }^{66}$ See Jon S. Vernick et al., Effects of Maryland's Law Banning Salurday Night Special Handguns on Crime Guns, 5 INJURY PREVENTION 259, 261 (1999). This study does not assess the overall effect of the law on crime; only if criminals do not substitute equally or more lethal guns for the inexpensive banned models will the overall effect be beneficial.

${ }^{67}$ See Jeffrey A. Roth \& Christopher S. Koper, The Urban Institute, Impact Evaluation of the Public Safety and Recreational Firearms Use Protection Act of $1994 \S 1.3 .1$ (1997) (visited Dec. 5, 1999) <http://www.urban.org/crime/aw/awfinall.htm> (reporting a reduction in police requests for ATF traces of semiautomatic assault weapons in the first calendar year after the federal ban took effect).

${ }^{2}$ See Colin Loftin et al., Effects of Restrictive Licensing of Handguns on Homicide and Suicide in the District of Columbia, 325 NEW ENG. J. MED. 1615, 1615 (1991).

${ }^{69}$ See generally Stephen P. Teret, Litigating for the Public's Heallh, 76 AMER. J. PUB. HEALTH 1027, 1029 (1986) (arguing that the response to liability exposure in products liability litigation should be the marketing of safe products, not limitations on litigation, and that litigation provides the only de facto form of safety regulation for some products).

${ }^{70}$ See Hamilton v. Accu-Tek, 62 F. Supp. $2 d 802$ (E.D.N.Y. 1999).

${ }^{7}$ See Smith \& Wesson, Stocking Dealer Code of Responsible Business Practices (visited Nov. 21, 1999) <http://www.apbnews.com/newscenter/breakingnews/1999/10/22/ wessondoc.html $>$ (requiring dealers to comply with federal, state, and local regulations, to employ "trained and competent personnel," and to sell all Smith \& Wesson firearms with locking devices and all applicable safety and instruction manuals). 
other product-related areas include litigation against motor vehicle manufacturers who failed to provide air bags ${ }^{72}$ and against alcoholic beverage providers who served intoxicated persons who then injured others (called dram-shop liability). ${ }^{73}$

\section{SOME POSSIBLE OBJECTIONS TO REGULATING GUNS AS CONSUMER PRODUCTS ${ }^{74}$}

It may be argued ${ }^{75}$ that unlike other consumer products, firearms enjoy special status under the Second Amendment to the U.S. Constitution. ${ }^{76}$ The resulting argument might be that consumer product regulation of firearms would be unconstitutional. With only one very recent exception that is currently on appeal, ${ }^{77}$ however, no federal court has ever struck down any gun law as violative of the Second Amendment $^{78}$ The Supreme Court has not directly addressed the Second Amendment since $1939,{ }^{79}$ but based on the Court's rulings, lower federal courts have had remarkably little trouble concluding that the Second Amendment does not currently stand as an obstacle to even broad gun regulation. If laws completely banning handguns have passed constitutional muster, ${ }^{80}$ it is difficult to imagine how regu-

${ }^{72}$ See TOM GHRistoffel \& STEPHen P. Teret, Protecting the PUblic: Legal ISSUES IN INJURY PREVENTION 166-67 (1993) (providing an overview of early litigation involving the failure to include airbags in automobiles).

73 See U.S. DEP'T OF HEALTH \& HUMAN SERVS., AICOHOL \& HEALTH 315 (1997).

${ }^{74}$ The purpose of this Part is to examine a number of possible objections to regulating firearms as consumer products. These may or may not be the same arguments made by David Kopel in the companion piece to this Article.

${ }^{75}$ In fact, this is a claim Kopel has briefly made elsewhere: "Another argument against treating guns like cars, of course, is that gun ownership is explicitly protected by the U.S. Constitution and by 44 state constitutions, while car ownership has no such special status." David B. Kopel, Taking it to the Streets, REASON, Nov. 1, 1999, at 45, 47.

${ }^{76}$ The Second Amendment states: "A well regulated Militia, being necessary to the security of a free State, the right of the people to keep and bear Arms, shall not be infringed." U.S. CONST. amend II.

7 See United States v. Emerson, 46 F. Supp. 2d 598, 610 (N.D. Tex 1999) (interpreting the Second Amendment to guarantee a personal right to bear arms).

${ }^{78}$ See Jon S. Vernick \& Stephen P. Teret, Firearms and Heallh: The Right to be Armed with Accurate Informlation About the Second Amendment, 83 AMER. J. PUB. HEALTH 1773, 1774-76 (1993) (providing a summary review of Second Amendment federal court jurisprudence).

${ }^{79}$ See United States v. Miller, 307 U.S. 174, 183 (1939) (holding that a criminal prosecution under the National Firearms Act did not violate the Second Amendment).

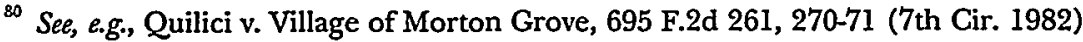
(asserting that the "second amendment does not apply to the states" and that a village gun-control ordinance did not therefore violate the Constitution), cert. denied, 464 U.S. 863 (1983). 
lations requiring design or marketing changes could run afoul of the courts' current narrow interpretation of the Second Amendment. ${ }^{81}$

Some may believe that education alone is sufficient to protect children and others from gun violence, or at least from gun accidents. In fact, the NRA's primary response to accidental deaths among children has been its "Eddie Eagle" curriculum, designed to teach children that they should "Stop, Don't Touch, Leave the Area, and Tell an Adult" if they find a gun. Unfortunately, there is no evidence that the natural curiosity of children can be stemmed so easily. One recent study demonstrated that a small group of children who received a similar educational intervention were no less likely to play with guns in a controlled setting than those who had not received the intervention. $^{82}$ Educating parents about safe storage practices, like keeping guns locked up and unloaded until ready to use, may also not work in

${ }^{81}$ In two nineteenth-century cases, United States v. Cruikshank, 92 U.S. 542 (1876), and Presser v. Illinois, 116 U.S. 252 (1886), the Supreme Court concluded that the Second Amendment is inapplicable to state laws. Although these cases precede the Court's use of the incorporation doctrine-applying portions of the Bill of Rights to state laws through the Fourteenth Amendment-they remain the Supreme Court's last word on the subject, and the Second Amendment has never been so incorporated.

Regarding federal laws, in United States v. Miller, 307 U.S. 174 (1939), the Court held that a criminal conviction under the 1934 National Firearms Act, which prohibited transporting unregistered machine guns or sawed-off shotguns in interstate commerce, did not violate the Second Amendment. In its decision, the Court gave effect to the opening "militia" clause of the Amendment, writing that

[i]n the absence of any evidence tending to show that possession or use of a "shotgun having a barrel of less than eighteen inches in length" at this time has some reasonable relationship to the preservation or efficiency of a well regulated militia, we cannot say that the Second Amendment guarantees the right to keep and bear such an instrument.

Id. at 178 (citing Aymette v. State, 21 Tenn. ( 2 Hum.) 154, 158 (1840)).

Recently there has been a substantial amount of new scholarship arguing that the Second Amendment should be read to grant an individual right to keep and bear arms, not one that is solely militia-related, applicable to both state and federal laws. See, e.g., Don B. Kates, Handgun Prohibition and the Original Meaning of the Second Amendment, 82 MICF. L. REV. 204 (1983); William Van Alstyne, The Second Amendment and the Personal Right to Arms, 43 DUKE L.J. 1236 (1994). Although this scholarship provides interesting arguments regarding what the Second Amendment should mean, with only one anomalous exception (United States v. Emerson, 46 F. Supp. 2d 598 (N.D. Tex. 1999)), no federal court has ever struck down any gun law as violative of the Second Amendment. In fact, in a number of recent, high-profile challenges to federal gun laws, opponents have not even raised the Second Amendment as an argument. See Vernick \& Teret, supra note 45 , at 1713,1721 . For now at least, arguments that even broad gun control laws violate the Second Amendment-much less that narrower consumer product regulation would-lack a foundation in judicial rulings.

${ }^{82}$ See Marjorie S. Hardy et al., A Firearm Safety Program for Children: They Just Can't Say No, 17 J. DEV. \& BeHAV. PEDIATRICs 216, 219 (1996) (finding no significant reduction in "gun play" after controlled intervention). 
all cases. In fact, one study found that adults who had received some form of firearm training were actually less likely to safely store their firearms locked up and unloaded. ${ }^{83}$ Certainly, parents who insist on having guns in their home have a responsibility to instill safe behaviors in themselves and their children. Education alone, however, may not be as effective as building safety into the design of the product itself. $^{84}$

The steady decline in both the number and rate of accidental firearm-related deaths in the United States is also sometimes cited as a reason why consumer product regulations are not needed. There remain about 1,000 accidental gun deaths each year. ${ }^{85}$ In addition, as has been described, comprehensive regulations can affect more than just accidental deaths-the risk of suicide and homicide may be also be reduced.

David Kopel has elsewhere argued that "loaded guns can be good for kids. ${ }^{\text {"86 }}$ One part of this argument is that law-abiding parents need guns (and apparently loaded guns) to prevent a criminal attack. This reasoning draws upon research purporting to show that firearms are used many times each year by civilians to thwart criminal attacks. ${ }^{87}$ Subsequent analyses have strongly suggested that this research has probably greatly overestimated the number of defensive uses of guns. ${ }^{8 s}$ Whatever the true number of defensive uses, however, design standards or other consumer-product regulation need not interfere with the ability of law-abiding citizens to obtain some firearms. Furthermore, personalized guns or other technology should not affect the reliability of firearms.

${ }^{8 s}$ See David Hemenway et al., Firearm Training and Storage, 273 JAMA 46, 48 (1995) (finding that in a random digit-dial telephone survey of 800 firearm owners, those who had received firearm training "are more likely to keep a gun loaded and unlocked than those who have received no training").

${ }^{84}$ See generally LEON S. ROBERTSON, INJURY EPIDEMIOLOGY (1992).

${ }^{\text {as }}$ See Hoyert et al, supra note 6, at 68 tbl.16 (reporting 981 accidental deaths caused by firearm missile in 1997).

${ }^{86}$ Kopel \& Volokh, supra note 65.

${ }^{87}$ See Gary Kleck \& Marc Gertz, Armed Resistance to Crime: The Prevalence and Nature of Self-Defense with a Gun, 86 J. CRIM. L. \& CRIMINOLOGY 150, 164 (1995) (estimating that private citizens use firearms in response to criminal attacks approximately $2.5 \mathrm{mil}-$ lion times annually in the United States).

${ }^{\text {\& }}$ See, e.g., COOK \& LUDWG, supra note 1, at 8-10 (explaining why surveys like that of Kleck and Gertz greatly overestimate the number of defensive gun uses); David Hemenway, Survey Research and Self-Defense Gun. Use: An Explanation of Extreme Overeslimates, 87 J. CRIM. L. \& CRIMINOLOGY 1430, 1431 (1997) (suggesting that the Kleck and Gertz survey was characterized by "severe misestimation"). 
Kopel has also claimed that some design standards for firearms "will, like automobile safety rules, cause the deaths of innocent people.." ${ }^{, 9}$ As evidence, he cites deaths associated with passenger-side air bags in cars. But the net effect of the safety standard requiring air bags has been to save an estimated 2263 lives from 1987 to $1997 .^{90}$ As examples of potentially dangerous firearm regulations, Kopel cites trigger locks that "can cause a loaded gun to fire when it is dropped" and magazine safeties that might "prevent a gun owner from firing his weapon when he is attacked." ${ }^{91}$ We do not advocate trigger locks: they are not part of a firearm's original design; they require the gun owner to always remember to use the lock, and, as a result, they are less likely to be effective than the automatic protection afforded by personalized guns. There is no evidence that lives have been lost because a gun had a magazine safety, much less that the net effect of these devices is harmful.

Finally, some may believe that the real way to prevent firearm deaths and injuries is through other interventions. For example, the NRA and others suggest that better enforcement of existing laws can reduce the risk of firearm violence. No one should believe that consumer-product regulation will prevent all gun deaths and injuries. We agree that better and more targeted enforcement of gun laws is important. We see no reason why this cannot be done in addition to effective consumer-product regulation, rather than in its place.

\section{CONCLUSION}

Firearms have long enjoyed a privileged status in American life. Although the sale, possession, and use of firearms is already more strictly controlled than most other consumer products, the special risk of harm associated with firearms justifies this regulation. Yet in the area of design, manufacture, and marketing, firearm manufacturers have remained largely free to do as they please. The decisions these manufacturers make, however, affect not just their own bottom line, and not even only their gun-owning customers, they affect us all. Enhanced product-based regulation of firearms might indeed force

${ }^{89}$ Kopel, supra note 75, at 46.

90 See NaTIONAL HighWAY TRAFFic SAFETY ADMIN., U.S. DEP'T OF TRANSP., EFFECIIVENESS OF OCCUPANT PROTECTION SYSTEMS AND THEIR USE, FOURTH REPORT TO CONGRESS at i (1999) (reporting that air bags saved an estimated 2263 lives from 1987 to 1997).

${ }^{91}$ Kopel, supra note 75 , at 46. 
manufacturers to innovate, and customers to pay perhaps a bit more. Surely these are acceptable trade-offs to minimize the societal risks that firearms pose. 
$*$ 